\title{
EFFECTIVENESS OF GAMIFICATION ELEMENTS IN BLENDED LEARNING ENVIRONMENTS
}

\author{
Dr. Can MESE \\ ORCID: 0000-0002-9759-7055 \\ Faculty of Education, Yozgat Bozok University \\ Yozgat, Turkey \\ Dr. Ozcan Ozgur DURSUN \\ ORCID: 0000-0002-5866-5748 \\ Faculty of Education, Anadolu University \\ Eskisehir, Turkey
}

Received: 31/01/2019 Accepted: 18/02/2019

\begin{abstract}
The purpose of this study was to determine the effectiveness of blended learning environments enriched with the use of gamification elements. The study was carried out using the convergent parallel mixed design, in which the qualitative and quantitative data were integrated. The study was conducted with 63 participants who were randomly divided into control and experimental groups. In the experimental group, the activities were enriched in the environment by using the gamification elements but not in the control group. The data were collected by Community of Inquiry data collection tool, academic achievement test, Instructional Materials Motivation Survey, experience activity, and interviews. According to the results, no difference was observed between the groups in terms of community of inquiry model, academic achivement, motivation. These findings are supported by qualitative data. According the findings, it could be stated that learning occurred in the form of latent learning in the experimental group.
\end{abstract}

Keywords: Gamification, blended learning, community of inquiry, motivation.

\section{INTRODUCTION}

Technological developments change the structure of learning environments. Now, learning environments are transformed into a blended structure with face-to-face and online environment through web-based learning activities. In the field of educational technology, face-to-face and online environments have been compared within the context of their instructional qualities for long years. Today, rather than comparing these environments (Xu \& Jaggars, 2014), there are tendencies towards the establishment of blended learning environments, which bring superior aspects of these environments together (Garrison \& Vaughan, 2008). Related researches on blended learning points to the importance of putting these two environments into practice (Garrison \& Vaughan, 2008; So \& Brush, 2008; Vaughan \& Garrison, 2005).

Within the scope of blended learning, the face-to-face environment is used to allow learners' access, to increase their motivation and to establish interaction with each other via in-class activities, while different online applications are used for the same purposes in online environment. Examples of such online environments include social networks, Web 2.0 tools, MOOCS and Learning Management System (LMS) (Hoic-Bozic, Dlab \& Mornar, 2016). Among these environments, especially LMSs are widely used in online learning activities. LMS allows designing a special web-based teaching process involving the planning, application and evaluation of a course (Kidd, 2010). In addition, LMS provides different tools such as chat and discussion forums to support interactions and communications between student-student, studentcontent and student-teacher (Lonn, Teasley \& Krumm, 2011; Moore, 1989). In addition, LMS also brings 
about such advantages as submitting homework, accessing course materials, viewing the grades, guiding one's own learning, developing one's upper-level thinking skills and supporting group work (Islam \& Azad, 2015; Macfadyen \& Dawson, 2012).

Related research findings demonstrate that blended learning is more effective when compared to traditional education (Al-Qahtani \& Higgins, 2013; Chang et al., 2014; Drysdale, Graham, Spring, \& Halverson, 2013; Means et al., 2013; Smith \& Suzuki, 2015). Despite these potentials of blended learning, increasing interest in the learning material (Nsibande, 2014), monitoring and managing students' participant progress (Kanchanamala \& Muppidi, 2016), and learning interactions (Draffan \& Rainger, 2006) are among the challenges in blended learning. In addition, how to make blended learning environments more effective is still an issue of debate among a number of researchers (Moskal, Dziuban \& Hartman, 2013). In order to increase the effectiveness of blended learning and to overcome the related difficulties, several studies have been conducted within different research contexts (Halverson et al., 2014), and based on the results of these studies, various methods and models have been suggested (Graham, Henrie \& Gibbons, 2014). For instance, a blended learning model enriched with Web 2.0 tools was suggested and examined with respect to academic achievement by Hoic-Bozic, Dlab and Mornar (2016). As another example, Staker and Horn (2012) suggested a four-structure model for K-12. Moreover, the concept of gamification, which has been investigated intensively in recent years, has the potential to increase the effectiveness of blended learning and to overcome the related difficulties. In recent years, the extent to which gamification, which is based on the use of game-related characteristics in out-of-game environments, is effective in blended learning environments has been a matter of debate (Harman, Koohang \& Paliszkiewicz, 2014). Therefore, the present study aimed to determine the effectiveness of gamification in blended learning environments.

\section{LITERATURE REVIEW}

\section{Blended Learning}

Blended learning is a concept which has been emerged from powerful aspects of face-to-face and online learning (Garrison \& Vaughan, 2008; Vaughan, Cleveland-Innes \& Garrison, 2013). In practice, advantages of both environments are blended by gathering them within the context of in-class and online activities in a way to be consistent with the curriculum (Garrison \& Vaughan, 2008). According to Staker and Horn (2012), in blended learning, students learn at least in part through online learning, and learn at least in part at a supervised brick-and-mortar location away from home. The studies on blended learning mostly focus on the environment-method discussion. In most of these studies, blended learning and traditional learning were compared (Al-Qahtani \& Higgins, 2013; Chang et al., 2014; Drysdale et al., 2013; Hamza, 2015; Smith \& Suzuki, 2015), and it was found that students in blended learning environments had higher levels of achievement, motivation and attitudes when compared to those in traditional learning environments (Caputo, 2010; Drysdale et al., 2013; Hebebci \& Ertugrul, 2015; Tuysuz \& Balaman, 2011). Besides these studies, Cheng and Chau (2016) reported significant relationships between learning styles of learners and their online participation, between online participation and academic achievement and between achievement and satisfaction. In addition, in related researches, there are several other studies comparing online learning and blended learning (Drysdale et al., 2013; Hoic-Bozic, Dlab \& Mornar, 2016; Patchan et al., 2015).

The studies have been carried out over the last decades to improve the effectiveness of online learning and blended learning. One of the related models is that of the Community of Inquiry (CoI) (Garrison, Anderson \& Archer, 2010; Golding, 2015). This model suggests supporting online learning with the cooperative and constructive view point and increasing the effectiveness (Arbaugh et al., 2008). According to the CoI model, learning occurs with the interaction of the elements of social, cognitive and teaching presence (Garrison, Anderson \& Archer, 1999).

In related literature, there are various studies on the indicators of the CoI model. In their study conducted to determine the indicators of the CoI model, Scott, Sorokti and Merrell (2016) reported that gamification had a positive effect, while Yildirim (2017) points out gamification-supported blended learning has positive impact on students' attitudes towards the lesson. Besides, according to the analysis of the studies about gamification is done by Dicheva, Dichev, Agre and Angelova (2015), gamification of blended learning 
courses is the major in the studies. Therefore, in order to determine the effectiveness of gamification in blended learning environments, there is a need for these three elements as well as for the indicators of these elements.

\section{Gamification}

Growing of gamification, both in practice and in the field of research (Dichev \& Dicheva, 2017, is defined by researchers in different ways (Deterding et al., 2011; Marczewski, 2015; Werbach \& Hunter, 2012; Zichermann \& Cunningham, 2011). Also, gamification is defined by as use of game design elements in non-game contexts. Gamification is also referred to by Zichermann and Cunningham (2011) as use of game thinking and game mechanics to engage users and to solve problems. According to the most comprehensive definition of gamification put forward by Kapp (2012), "gamification is using game-based mechanism, aesthetics and game thinking to engage people, motivate action, promote learning, and solve problems". As mentioned in the definitions reported in related literature, gamification can be regarded as use of such elements of games as badges, experience point, leaderboard and level in non-game contexts. According to studies about the gamification; it is seen that the elements such as score, point, badge, aim and goals, leaderboard, feedback, reward, experience, achievement, profile, difficulty, challenge, level, virtual goods, progress bar are used in gamification environments (Koivisto, \& Hamari, 2019; Cuhadar, \& Akgun, 2018; Subhash, \& Cudney, 2018). In order for gamers to know what they do in games and why they do these things (Marczewski, 2015), the goals are set clearly in games (Kapp, 2012). Therefore, in a gamified environment, each element of gamification, the goals, the missions and the functioning of the gamified environment should be clarified. In addition, in gamified, the point is effective in such issues as monitoring the progress, management of awards, wining badges, and the leaderboard (Marczewski, 2015), and participants are awarded (Kapp, 2012). Besides, experience point is used as one of feedback tools (Aldemir, Celik, \& Kaplan, 2018). In this respect, experience point is used to reveal and award individuals' progress in the gamified environment. Leaderboard which is an important tool for participants to see their position instantly in gamified environments (Marczewski, 2015; Mert, \& Samur, 2018), has an important place in facilitating learning as well as in encouraging learners (Zichermann \& Cunningham, 2011). Moreover, the experience scores of the participants change through the points, in this way, participants can learn about their experiences in a gamified environment (Kapp, 2012; Werbach \& Hunter, 2012. Also, awards can be effective in strengthening individuals' behaviors in the behaviorist viewpoint (Werbach \& Hunter, 2012). Badges which are icons that appear on participants' profile pages if they accomplish the previously assigned missions (Werbach \& Hunter, 2012) can be preferred as virtual rewards and determine their positions in gamification environments (Zichermann \& Cunningham, 2011). Badges can be used a tool recording students' academic achievements in LMS (Marczewski, 2015) Moreover, badges are virtual rewards obtained via a certain effort or achievement, they are not an objects distributed free (Zichermann \& Cunningham, 2011). Feedback used as another tool in the gamification environment is often preferred. It also can be an effective method supporting students to direct to intended behaviors (Werbach \& Hunter, 2012; Zichermann \& Cunningham, 2011). The feedback tools can be prefered in gamified environments so as to learn about the accuracy or inaccuracy of a particular behavior (Kapp, 2012). Gamification elements like experience point, level and progress bar can be used to provide feedback in gaming environments.

In literature, there are several studies considering gamification within the context of academic achievement. $\mathrm{Su}$ and Cheng (2015) state that mobile learning supported with gamification is more effective in terms of academic achievement when compared to traditional teaching, while Kuo and Chuang (2016) point out that gamification draws users' attention with respect to academic development, increases engagement between them and motivates them. In addition, there are several other studies investigating the effectiveness of badges, one of the elements of gamification. Davis and Singh (2015), in their study, found that badges helped motivate learners, keep records of their achievements and control their own learning. Besides the positive effects of gamification like academic achievement, motivation, interests and attitudes, its negative effects are being investigated in related literature as well. Hanus and Fox (2015) claim that gamification has negative effects of motivation, level of satisfaction and academic achievement. It has also been examined in terms of motivation the fact that recent studies carried out on game and gamification have focused on the influence of the elements of gamification (Davis \& Singh, 2015; Domínguez et al., 2013; Hanus 
\& Fox, 2015; Kuo \& Chuang, 2016; Mekler, et al., 2017; Yilmaz \& O'Connor, 2016). In the scope of the research, effectiveness of gamification elements in blended learning was examined in terms of learning through looking to the academic achievement, and motivation and $\mathrm{CoI}$ as they are effective in the formation of academic achievement in general.

Motivation which is a major focus of learning constitute another research topic in related literature about gamification. Yilmaz and O'Connor (2016) point out that the software development process supported with gamification increase both learners' motivation and their participation. Domínguez et al. (2013) claim that gamification is emotionally and socially effective and that the system of award and competition motivates learners. Seixas, Gomes and de Melo Filho (2016) reports that gamification is an effective method to create engagement amongst students.

Considering that blended learning is more effective than the traditional way of teaching (Al-Qahtani \& Higgins, 2013; Chang et al., 2014; Drysdale et al., 2013; Means et al., 2013; Smith \& Suzuki, 2015; Tamim et al., 2011), it could be stated that instead of comparison of blended learning with traditional teaching, studies on overcoming the difficulties in blended learning and on increasing its effectiveness come into foreground. As stated by Garrison and Vaughan (2008), there is a need for the CoI model to determine the potential of blended learning. Therefore, the effectiveness of the elements of gamification in blended learning environments was examined within the framework of $\mathrm{CoI}$ model. According to $\mathrm{CoI}$ model, since learning occurs with the interaction of the elements of social, cognitive and teaching presence (Garrison, Anderson $\&$ Archer, 1999), the effectiveness of the elements of gamification in blended learning environments was examined within the framework of these three elements and the indicators of these elements (Table 1).

Table 1. Elements, categories and indicators of CoI model (Garrison \& Arbaugh, 2007)

\begin{tabular}{ccc}
\hline Elements & Categories & Indicators \\
\hline \multirow{2}{*}{ Teaching presence } & Design \& Organization & Setting curriculum \& methods \\
& Facilitating Discourse & Sharing personal meaning \\
& Direct Instruction & Focusing discussion \\
\hline Social presence & Open communication & Risk-free expression \\
& Group Cohesion & Encourage Collaboration \\
& Affective expression & Emoticons \\
\hline \multirow{2}{*}{ Cognitive presence } & Triggering Event & Sense of puzzlement \\
& Exploratory & Information exchange \\
& Integration & Connecting ideas \\
\hline
\end{tabular}

In the current study, the purpose was to investigate the effectiveness of gamification elements in blended learning environments within the context of teaching, social and cognitive presence, academic achievement and motivation. In line with this purpose, this study addressed the following research questions:

1. What is the influence of gamification elements on participants' teaching, social and cognitive presence?

2. What is the influence of gamification elements on participants' academic achievement?

3. What is the influence of gamification elements on participants' motivation?

\section{METHOD}

As the research design to be applied in the study, the Convergent Parallel Mixed Methods Design was used (Creswell, 2014). In the study, the quantitative and qualitative data were collected simultaneously within a 13-week schedule and related with each other for analysis. The research process is given in Figure 1. 


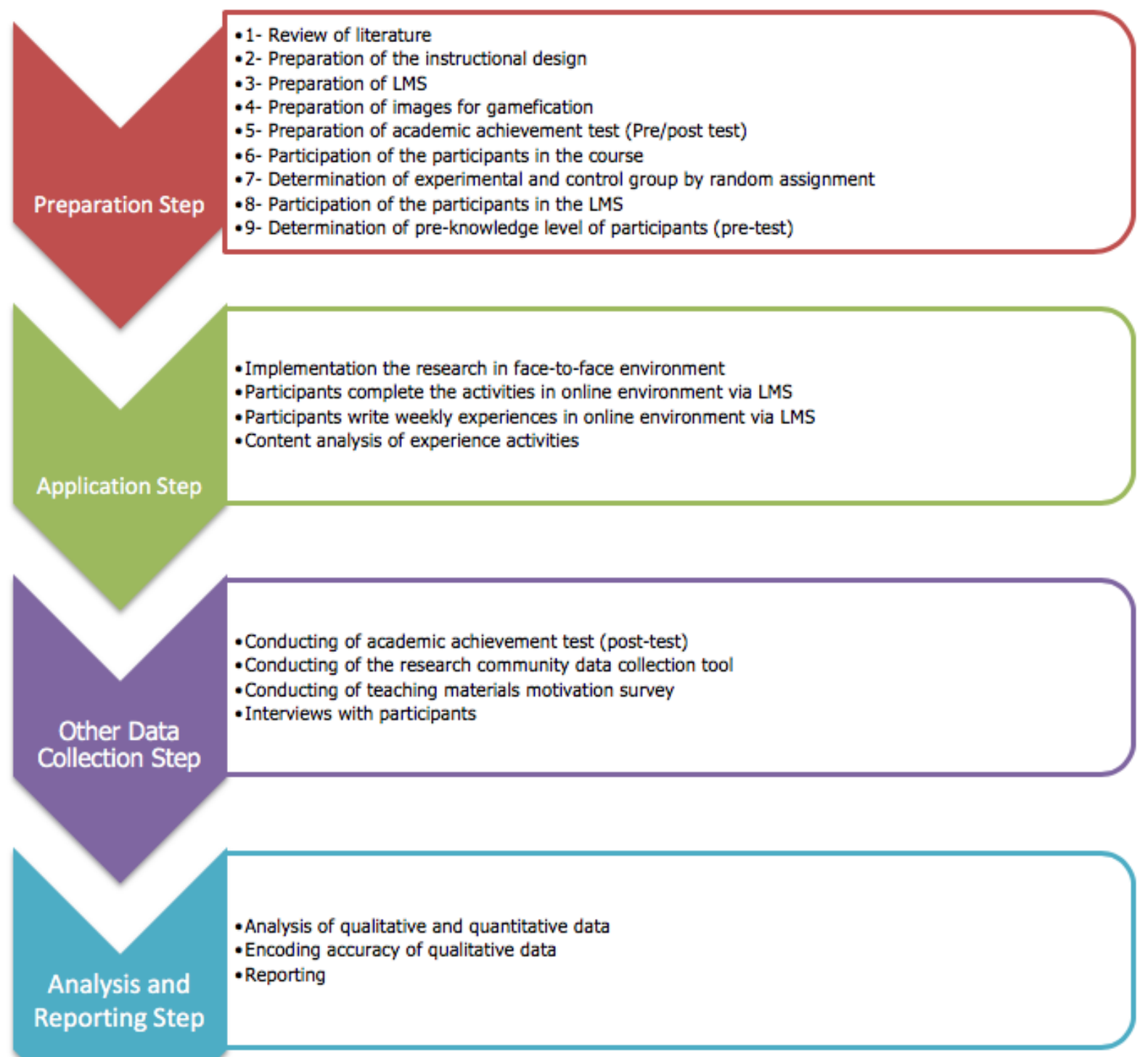

Figure 1. The steps of research process

\section{Participants}

The participants of the study were 63 freshman students (30 experimental, 33 control group) taking the course of Information Technologies in Education-I given. As freshman students are expected to have low levels of awareness of an experience in online learning, the participants of the study were selected especially among freshman students. In addition, since the goal of the related course is to develop students' knowledge about and skills in computer sciences, the research topic and the application process are consistent with the objectives of the course. The ages of the participants ranged between 18 and 27, and the mean of their age is 19 in the current study.

In line with the primary purpose of the study, the course was set for two classes of students, the participants were assigned to these two groups on random basis. Also, one of these two groups were determined as the experimental group and the other as the control group again randomly. Therefore, the simple random sampling method was used to determine the participants in the study (Fraenkel, Wallen \& Hyun, 2011). 


\section{Data Collection and Analysis}

The research data were collected via the community of inquiry data collection tool, academic achievement test, Instructional Materials Motivation Survey, experience activity, semi-structured interviews and focus group interview.

\section{Community of Inquiry (Col) Data Collection Tool}

For the purpose of determining the participants' perceptions regarding the online environment, the CoI measurement tool developed by Arbaugh et al. (2008) and adapted to Turkish by Ozturk (2012) was used. CoI tool was formed by three factors as teaching, social and cognitive presence. In the study, in relation to appropriateness of the measurement tool to the accepted factors reported in related literature, confirmatory factor analysis (CFA) was conducted using the software of Lisrel 9.1 for the data collected from 277 participants who individually experienced online learning in blended learning environment. The results obtained via CFA were interpreted based on the studies reported in related literature (Cokluk, Yilmaz \& Oguz, 2012; Hu \& Bentler, 1999; MacCallum, Browne \& Sugawara, 1996; Sumer, 2000; Tabachnick $\&$ Fidell, 2007). According to the findings obtained in these studies and the results obtained via CFA, it was seen that the model demonstrated fitness of good for a number of values (Chi-square: 1428.96, Chisquare/df: 2,73, p-value: .069, RMSEA: .081, SRMR: .057, NFI: .957, NNFI: .970, CFI: .972, GFI: .739, AGFI: .703). Since the GFI value is sensitive to the sample size, the model was accepted without doing any modification on the model or without excluding any times though the GFI value demonstrated a low level of goodness of fit (Sharma et al., 2005). Within the scope of the present study, the whole scale $(a=.94)$ and the teaching $(\mathrm{a}=.89)$, social $(\mathrm{a}=.82)$ and cognitive presence factors of the scale $(\mathrm{a}=.86)$ could be said to have a high level of internal consistency (Akbulut, 2010; Ozdamar, 2004).

\section{Academic Achievement Test}

In the study, for the purpose of determining the background knowledge and academic achievements of the participants, an academic achievement test was developed. For this test, a total of 125 multiple-choice questions used in previous exams conducted within the scope of the course were classified considering the difficulty levels of the 13 lesson subjects constituting the content of the course. While determining the questions to be included in the achievement test, special attention was paid to balanced distribution of the questions in terms of their difficulty levels not only to ensure content validity with respect to the lesson subjects but also to develop a reliable measurement tool. The reliability coefficient based on the item variance of the test was examined with the method of Kuder-Richardson 20 (KR-20), and the value obtained was .501 for the pretest and .585 for the posttest. The KR-20 value depends on the context, goals and the length of the test, and the reliability coefficient of tests developed by teachers is expected to range between .50 and .85 (Miller, Linn \& Gronlund, 2009).

\section{Instructional Materials Motivation Survey (IMMS)}

In the study, in order to determine the participants' levels of motivation, the Instructional Materials Motivation Survey developed by Keller (2010) and adapted into Turkish by Kutu and Sozbilir (2011) was used. The original version of this measurement tool was made up of four factors, while the one adopted into Turkish included two factors attention-relevance and confidence-satisfaction with explained about $\% 45$ of the variance. In the study, the Cronbach Alpha internal consistency coefficients of the measurement tool (a) was calculated as .84 for the factor of attention-relevance, .71 for the factor of confidence-satisfaction and .87 for the whole scale. Since the value was higher than .80 , the measurement tool could be said to have a high level of reliability, but the dimension of confidence-satisfaction of the scale could be said to be moderately reliable (Akbulut, 2010; Ozdamar, 2004). 


\section{Experience Activity}

The experience activity is a data collection tool gathering participants' learning experiences about the blended learning process on weekly basis in LMS. The participants expressed their views on their motivation and satisfaction about blended learning process. The activity with a six-items semi-structured questionnaire form was presented to them every week, totally 13 weeks. During the experience activity, a total of 618 views were reported (334 views from the experimental group; 284 views from the control group).

\section{Interviews}

In the study, the semi-structured interviews and focus group interview were used as qualitative data collecting tools to find out answers for the research questions. Moreover, the semi-structured interviews were called as "interviews". They were performed with the participants face-to-face. For these interviews, the participants in the control group were chosen depending on their level of online participation and in the ones in the experimental group were chosen based on their leaderboard status in LMS. In this way, the participants with the highest, moderate and lowest levels depending on their participation in LMS were chosen using the maximum variation sampling method that is one of the purposeful sampling methods (Buyukozturk et al., 2014). The interviews were held with 41 participants from the two study groups in the middle and end of the research process. During these interviews, a semi-structured interview form including questions regarding the participants' sates of satisfaction and motivation was used.

The focus group interview in the experimental group was carried out in order to gather the views of the participants about gamified experience. It can be the best way to obtain people's opinions through a structured group conversation in which information is solicited by the moderator (Vaughn, Schumm \& Sinagub, 1996). With the interview, it was aimed to increase the variety of the data source in the qualitative dimension of study. The interview was conducted with 15 semi-structured questions in nine categories. During the beginning of this interview, two warm-up questions were used to help the participants to be ready for it. Then, it was held with six participants focusing on motivation, academic achievement, and teaching social and cognitive presence. The focus group interview was conducted in 107 minutes.

\section{Application}

Based on a blended learning model, the study was conducted with face-to-face and online learning environments. In the face-to-face, the researcher presented the course content as well as conducting applications on weekly basis in the computer class. In the online environment, it was conducted with Moodle (LMS) at any time of the day. Images of the environments where the study was conducted are given in Figure 2.

(Face to face)

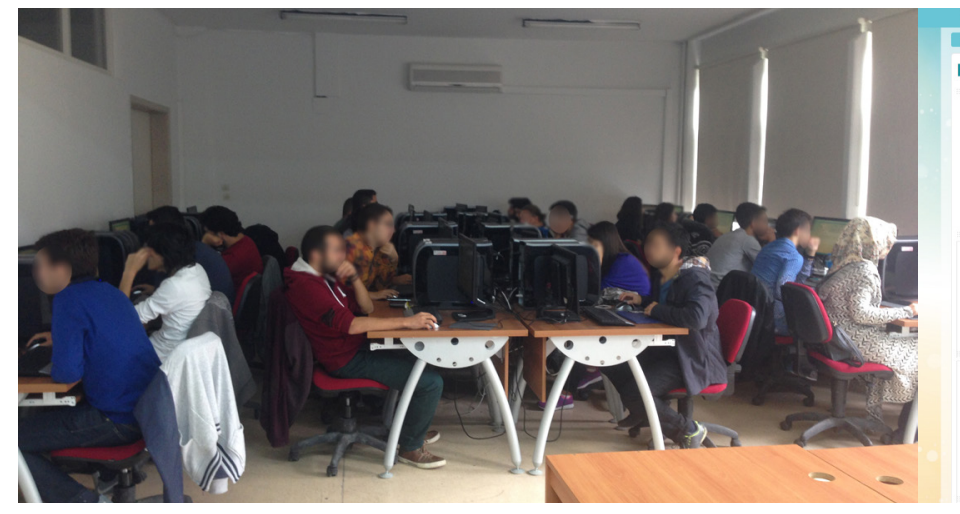

(Online)

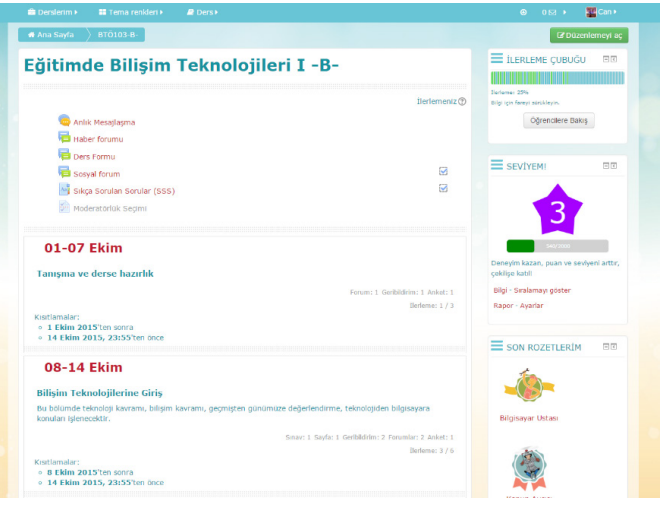

Figure 2. The environments where the study was conducted 
Two different courses were created in the LMS for online learning. General access section created for students to access at any time to some activity. A social forum activity and an instant messaging in this section were created so as to provide them the Moore's (1989) learner-learner interaction. In this section, it was aimed to provide the participants to make an interaction with their peer with the social forum activity.

As this study is based on blended learning, online activities were prepared being parallel to the face-to-face activities. These activities in LMS were constituted with such different plugins and modules of Moodle as forum, page, feedback, homework and exams. The experimental group was enriched with gamification elements thanks to Moodle's features and plugins and the face-to-face activities. None of these gamification elements were used in control group. According to theoretical grounds about related literature using of gamification elements in the experimental group were explained below and presented on Figure 3:

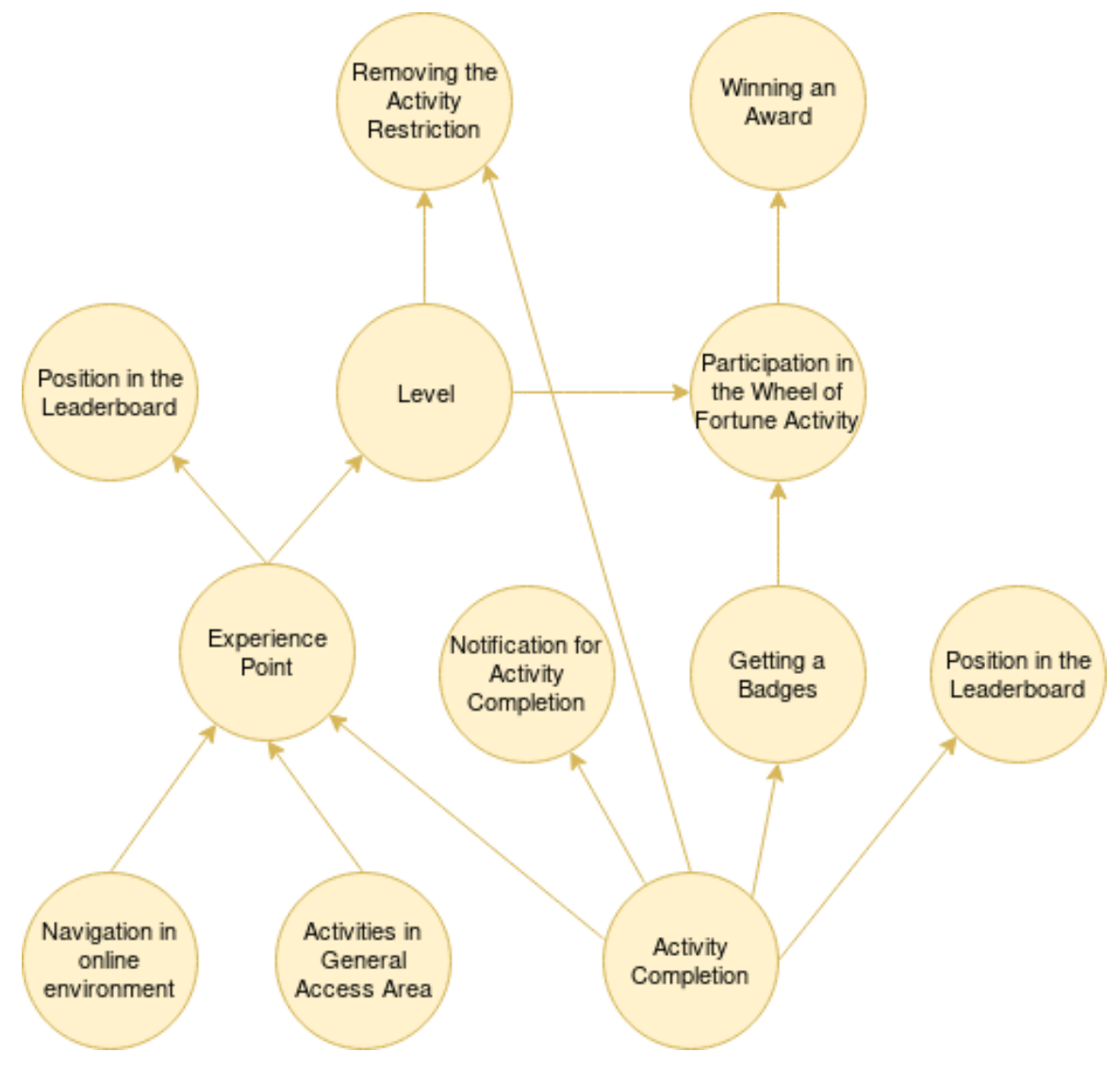

Figure 3. The gamification elements in the study

According to Zichermann and Cunningham (2011), user profile has an important role to award the users. The user profile was created in LMS in order to record the participants' achievements. The participants' information in the user profile was displayed.

The participants were scored using their actions on the LMS, such as messages sent in forums, events, and navigation. They earned experience points with these actions. They increased their levels, took a higher position in the leaderboard, got awards and obtained badges with the experience point. A leaderboard is an element of gamification is used as a user to compare with their own achievements with the others. For this purpose, two different leaderboards were formed to show their earned experience and completed activities points in LMS.

The participants were provided with feedback on their experiences and positions in the gamified environment. In the experimental group, a level system was created depending on the experience point and the participants gained a higher level when they gained certain experience points. The feedback about level up was shown instantly on the participants' screen as suggested by Zichermann $\&$ and Cunningham (2011). Also, feedback 
about activities were given with instant, direct and clear information to them via the progress bar, activityreminding e-mail and activity completion. The progress bar and leaderboard which is used as a feedback tool in this study are given in Figure 4.

Progress Bar

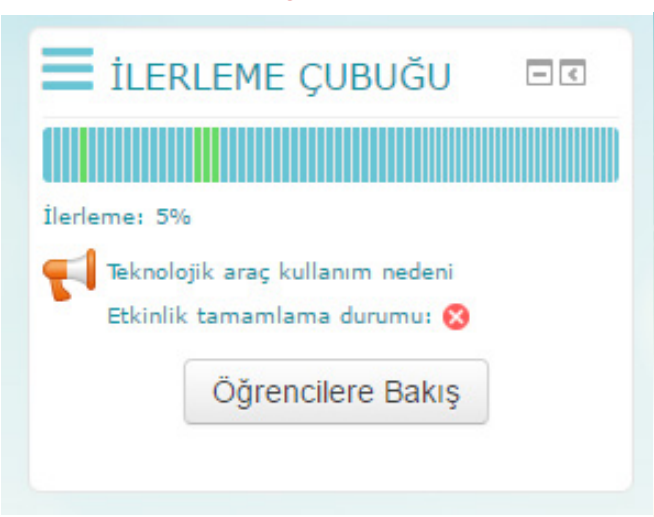

\section{Leaderboard}

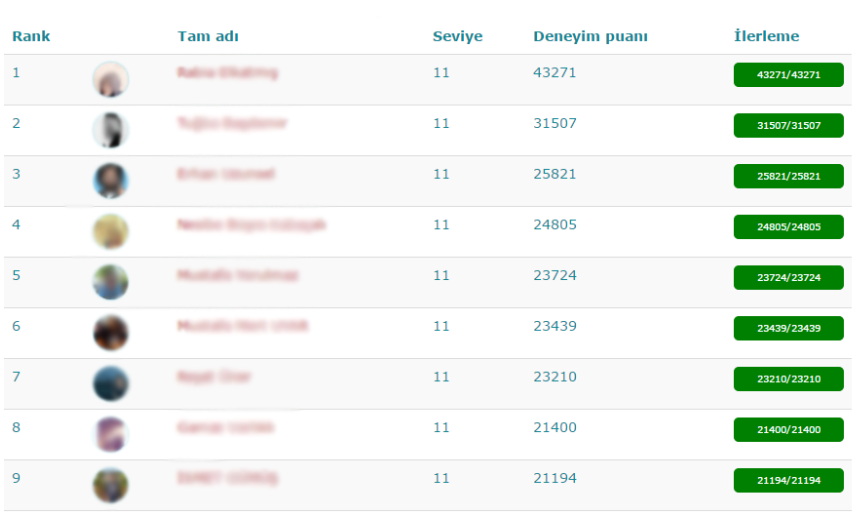

Figure 4. The feedback tools used in the study

Awards are effective tools in the development of individuals' behaviors (Werbach \& Hunter, 2012). Therefore, in the study, the experience point, badges and face-to-face award activity were used as awards to reward for the participants. When participants completed the activities in LMS, related badges were given instantly to award their behaviors and notify them about their positions in gamified environment (Gibson et al., 2015; Zichermann \& Cunningham, 2011). The badges were created and named with respect to related rules in the context of the activities. When they gained the badge of wheel of fortune or were the first to reach a certain level, they got the right to join the face-to-face award activity in face-to-face environment. Then, they turned the wheel of fortune (see Figure 5) the face-to-face environment and have won awards that can be used in or out of the gamified system. Moreover, according to Kapp (2012), the restriction could be a useful game element to motivate gamers. The activities were restricted according the time, level and completion of the prerequisite activities being specific to the context of weekly activities to motivate them in online learning.

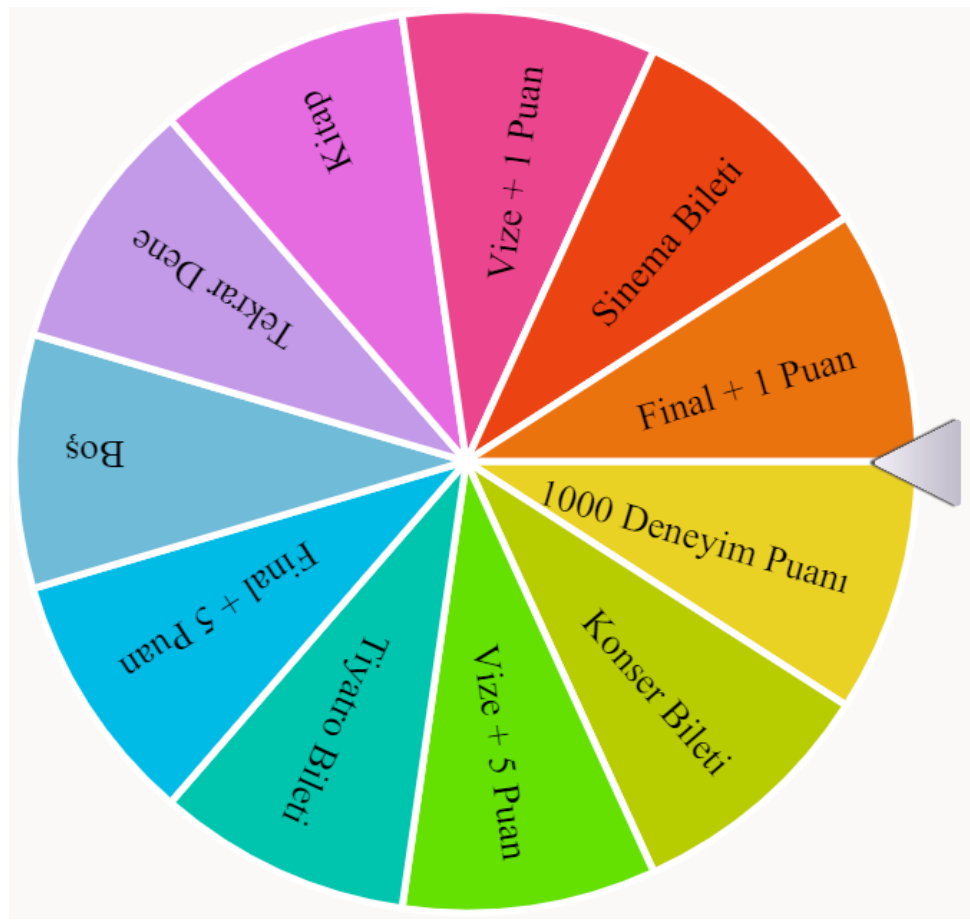

Figure 5. Wheel of fortune activity which is used in the research 


\section{Data Analysis}

The quantitative data in the study was analyzed with independent samples t-test, 2 X 2 mixed design ANOVA and Pearson product-moment correlation, while the qualitative data gathered from each data source were analyzed using content (inductive) analysis method within its own context.

After the qualitative data were analyzed separately within its own context of each data source, all the data were gathered under a single roof. Based on these data, the codes and themes were determined. For the direct quotations, the participants' personal information was kept confidential. In this direction, the sources of their views were determined as "E, Interview-3" referring to the third interview of the experimental group.

To ensure trustworthiness for the qualitative data, several strategies were used. In the study, since two researchers were involved in the research process, it was possible to take the views of more than one person. In addition, as the research process lasted 13 weeks, in-depth data were collected during and at the end of the research process. The qualitative data sources were diversified with experience activity, interviews and focus group interview. Also, the qualitative data collected by the researchers were coded again by an expert from the field of educational technologies, and appropriateness of the data was examined. Moreover, for the validity and reliability of the qualitative data, the codes and themes obtained were examined by two researchers' expert in the field of education technologies.

\section{FINDINGS}

This part presents the findings obtained via the quantitative and qualitative research data. Since the convergent parallel mixed design was used in the study, the findings are presented below by relating the qualitative and the quantitative data.

\section{Findings Regarding the Community of Inquiry}

The effectiveness of the gamification elements was examined with respect to the CoI model. Table 2 presents the descriptive findings in relation to the mean scores of the groups regarding the teaching, social and cognitive presence factors of the CoI model.

Table 2. Independent samples t-test results regarding the teaching, social and cognitive presence scores of the groups

\begin{tabular}{ccccccc}
\hline & Groups & $\mathrm{n}$ & $\overline{\mathrm{x}}$ & $\mathrm{SD}$ & $\mathrm{t}$ & $\mathrm{p}$ \\
\hline \multirow{3}{*}{ Teaching } & $\mathrm{C}$ & 33 & 4,05 & 0,61 & $-0,226$ & .822 \\
& $\mathrm{E}$ & 30 & 4,08 & 0,35 & & \\
Social & $\mathrm{C}$ & 33 & 3,91 & 0,60 & & $.0,047$ \\
& $\mathrm{E}$ & 30 & 3,92 & 0,46 & & .962 \\
Cognitive & $\mathrm{C}$ & 33 & 3,97 & 0,63 & & .906 \\
& $\mathrm{E}$ & 30 & 3,96 & 0,45 & 0,118 & \\
\hline
\end{tabular}

C: Control group (non-gamified blended), E: Experimental group (gamified blended)

In order to determine whether the mean scores for the factors were significant between the experimental and control groups, independent samples t-test was applied. The results revealed that there was no significant difference between the mean scores of the two groups with respect to the teaching, social and cognitive presence factors $(p>.05)$. For a more in-depth examination of this result, the data collected via the qualitative data collection tools were examined within the context of the CoI model indicators put forward by Garrison and Arbaugh (2007). 
The qualitative data regarding the teaching presence were examined within the context of the online activities in the online environment and within the context of the faculty member's teaching method in the faceto-face environment. The qualitative data were examined within the contexts of the online activities and the faculty member's teaching method, the former being in online environment and the latter in face-toface environment, both of which are the indicators of the teaching presence. The participants in the two groups reported that the faculty member's teaching method was interesting. In relation to this, one of the participants said, "I found the course content and the teaching style of the teacher quite interesting... (C, Experience-4)". In addition, the participants in the two groups stated that they were satisfied with the faceto-face lessons. Regarding this, one of the participants said, "I was pleased with the good teaching method used by the teacher (E, Experience-6)". The participants reported that their thoughts were considered via the online activities and that these activities were fairly interesting. Another indicator of the teaching presence focuses on sharing personal meaning. The participants stated that they felt comfortable while sharing their thoughts and emotions regarding this indicator in the face-to-face and online environments. In relation to this, one of the participants said "It was really good to use such a webpage in this course. I think it was more effective. I found the teachers interesting. I felt myself in comfort. I was happy to be here (E, Experience-6)".

The participants in both groups pointed out that the activities in the online environment were quite interesting since these activities were in the form of discussion and that this situation pleased them a lot. One of the participants who reported views about the activities in the online environment said "I was happy because the activities this week were easy, and they were mostly in the form of discussion. (E, Experience-5)". These findings demonstrated that consistent with the quantitative data obtained via the CoI data collection tool, the participants in the two groups reported similar views as supported by the qualitative data.

Within the dimension of social presence, social interaction between the participants was examined. In order to achieve social interaction between the participants, discussion activities were carried out in the online environment. In relation to this, the participants in the experimental and control groups reported similar views. One of the participants in the control group who responded to the question of how they felt said "Comfortable because for example, we shared information with friends we already know. (C, Interview-1)".

In the social forum activity prepared for the participants to establish social interaction between them, it was seen that they did sharing within the framework of different topics. In the control group, four discussion topics were started, and no response was given to these topics; on the other hand, in the experimental group, 358 discussion topics were initiated, and a total of 4915 responses were given go these topics. This difference between the two groups can be explained with the fact that the participants in the experimental group got an experience point with the use of the social forum. In relation to this, one of the participants said "For example, as the role of gamification in discussion activities, I need to do something in the forum to get a point. I have to join a discussion, I mean I have to do something there. (E, Focus group interview)". It was seen that the participants started discussions in the social forum or tended to join current discussions to get an experience point and that they thus were involved in social interactions. However, in the social forum activity, it was also found that participation only for the sake of getting an experience point caused other participants to develop negative emotions. In relation to this, one of the participants said "During the activities, the posts texted just to make a comment demoralize me. (E, Experience-7)".

According to the indicators of cognitive presence, it was seen that the participants focused on the importance of new knowledge. It was reported that new knowledge increases motivation, draws interest and leads to positive emotions. This situation was mentioned similarly in the experimental and control groups. One of the participants in the control group said "We got new knowledge via the activities, and we did better activities each passing week. (C, Experience-7)". Besides getting new knowledge in online environment, the participants also mentioned the importance of sharing the new knowledge. In relation to this, one of the participants said, "I liked sharing our knowledge in the forum (E, Experience-3)". It was found for both groups that the activities in online environment encouraged the participants to do search for information. The participants stated that they did search using the Internet and other sources of information to do the activities in online environment. According to these findings, the participants in the two groups reported similar views regarding the dimension of cognitive presence. 


\section{Findings Regarding Motivation}

In order to determine the effectiveness of gamification elements in blended learning environment, the data obtained via the interviews, focus group interview, experience activities and IMMS regarding the participants' motivation were examined. Table 3 presents the descriptive findings regarding the data obtained via IMMS.

Table 3. Independent samples t-test results regarding the attention-relevance and confidence-satisfaction mean scores of the groups

\begin{tabular}{lcccccc}
\hline & Groups & $\mathrm{n}$ & $\overline{\mathrm{x}}$ & $\mathrm{SD}$ & $\mathrm{t}$ & $\mathrm{p}$ \\
\hline \multirow{2}{*}{ Attention-relevance } & $\mathrm{C}$ & 33 & 3,77 & 0,59 & \multirow{2}{*}{.594} & \multirow{2}{*}{.555} \\
\multirow{2}{*}{ Confidence-satisfaction } & $\mathrm{E}$ & 30 & 3,85 & 0,47 & & \\
& $\mathrm{C}$ & 33 & 3,57 & 0,49 & .447 & \multirow{2}{*}{.657} \\
\hline
\end{tabular}

The attention-relevance and confidence-satisfaction scores of the groups were examined using independent samples t-test, and for these factors, no significant difference was found between the groups. In order to examine this situation in-depth, the qualitative data were used.

Although no significant difference was found between the motivations of the experimental and control groups depending on the quantitative data, the qualitative data revealed that gamification was influential on the participants' motivations to a certain degree. The influence of gamification on motivation was mentioned by a participant as follows: "To me, the gamification technique should be used in the following years as well. Our motivation was at its highest level. (E, Interview-3)". This view can be related with the dimension of volition defined in the ARCS-V model as transformation of intention to action (Keller, 2008). The participants' views that the gamification elements increased motivation was gathered under the codes of badge, experience point and activity completion. It was seen that both getting a badge and the appearances of the badges had positive influence on the participants' motivations. In relation to this, one of the participants said "The shapes of the badges had a motivating effect; it made us wonder what we would win when we completed the activity. Thus, we did the activities more quickly. (E, Interivew-3)". The participants reported that for their motivation, it was important for them to get a point via their experiences in online environment. In relation to this, one of the participants said "It increased my motivation. For example, you gave us homework. It was not just simple homework actually. At the same time, it would bring me points, and my points would increase ... (E, Interview-1)". The participants thought that they felt themselves more successful as they got experience points and that their levels of participation increased accordingly. This increase in the participants' levels of satisfaction helped increase the participants' motivations. In addition, it was seen that the experience point increased the participants' motivations with respect to the leaderboard, winning awards, maintaining competitiveness and reaching a higher level. The participants tended to get experience points to reach higher levels and to remove the activity restrictions. One of the participants mentioned the influence of level on motivation saying "I had a good motivation because I was ambitious to reach a higher level, and I used the website more. (E, Experience-10)".

The participants tried to get experience point to compete with the other participants and worked harder when they saw their opponents got experience points. Therefore, it was seen that being competitive by getting experience points increased the participants' motivations. In relation to this, one of the participants said "...for example, as my friends used it, I went online every day to catch them. Thus, it influenced my motivation positively. When I saw my friends getting points, I used the online environment more. I started to learn... (E, Interview-1)". In addition, it was seen that the experience point increased the participants' motivations as it allowed winning awards and influenced the participants' positions in the leaderboard. The participants made efforts to get experience points to be at higher levels in the leaderboard, and their motivations increased as they took a place at higher levels in the leaderboard. In relation to this, one of the participants said "My motivation was high because after long weeks, I ranked first in LMS. This increased my motivation (E, Experience-10)". When the activities were completed in the experimental group, a notification of activity completion appeared next to the activities, and this notification was found to have 
positive influence on the participants' motivations. In relation to this, one of the participants said "when all of them are ticked, it increases your motivation. If there is no tick, then you feel there is something missing (E, Interview-3)".

The gamification elements had negative influence on motivation in certain respects. The participants' views that the gamification elements decreased their motivation were gathered under three main headings: restriction, experience point and activity completion. The restrictions were rules that the participants had to meet to access the activities of the following week. When the previous activities were not completed or when the necessary level was not reached, the restrictions for the activities were not removed. It was found that these restrictions decreased the participants motivation. In relation to this, one of the participants said "This week, my motivation was rather low because my next activities were not opened. (E, Experience-7)". It was found that the participants' loss of the leading position in the leaderboard or their lower-level position in the leaderboard had negative influence on their motivation. One of the participants mentioned this situation saying, "My motivation decreased unavoidably when I lost my leading position in the leaderboard (E, Interview-2)". In addition, the participants reported that the notification for activity completion had negative influence on their motivation besides its negative effects. Regarding this, one of the participants said "Well, your motivation decreases if you do not do even one of them. For example, this was also the case for me (E, Interview-3)".

\section{Findings Regarding Academic Achievement}

In order to examine the effectiveness of gamification in blended learning in terms of academic achievement, the participants' levels of academic achievement were measured using pretest and posttest. The pretest scores of the participants in the experimental group $(\bar{x}=46,55 ; S D=1,97)$ and of those in the control group $(\bar{x}$ $=46,67 ; \mathrm{SD}=2,30)$ increased in the posttest for the experimental group $(\overline{\mathrm{x}}=58,55 ; \mathrm{SD}=2,37)$ as well as for the control group $(\overline{\mathrm{x}}=61,87 ; \mathrm{SD}=2,20)$. Figure 6 presents this change in the scores of the groups.

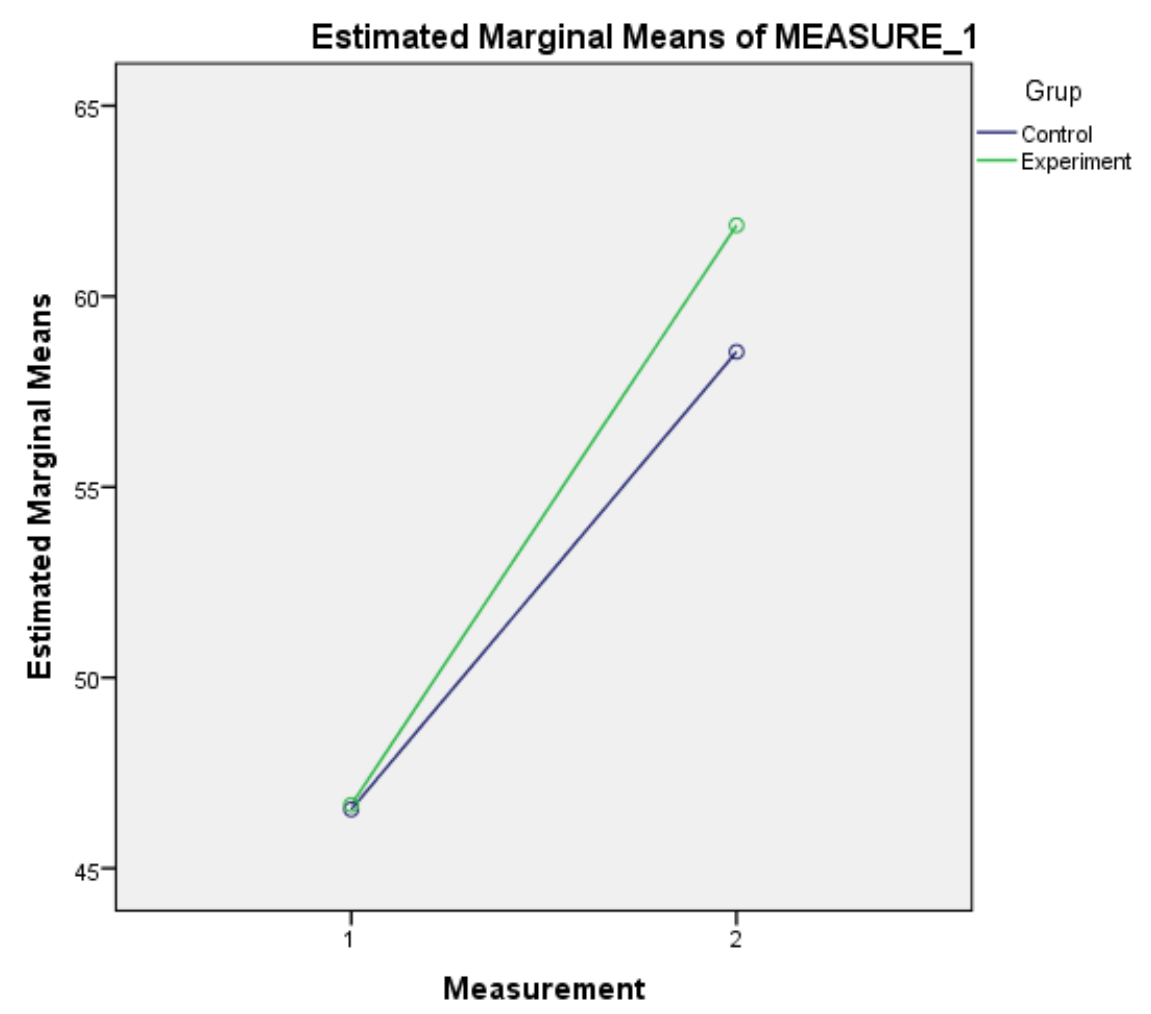

Figure 6. Graphical presentation of the change in the pretest and posttest scores of the groups

According to Figure 6, it is important to note that the two groups had similar pretest scores while their scores increased in the posttest. In order to examine the combined interaction of the increase in the posttest scores, 2 (experimental and control groups) X 2 (pre and post-test) mixed ANOVA was conducted. For the 
prerequisite assumptions of this test, Box's $\mathrm{M}(\mathrm{p}=.608)$ and Levene $\left(\mathrm{p}_{\text {pre-test }}=.712\right.$ and $\left.\mathrm{p}_{\text {post-test }}=.466\right)$ tests were applied, and it was seen that these assumptions were ensured. Table 4 presents the results obtained via the 2 $\mathrm{X} 2$ mixed ANOVA test in relation to the pretest and posttest of the groups.

Table 4. Results of 2 X 2 mixed ANOVA test regarding the pretest and posttest of the groups

\begin{tabular}{|c|c|c|c|c|c|c|}
\hline Sources of Variance & Sum of squares & SD & Mean square & $\mathrm{F}$ & $p$ & $\eta 2$ \\
\hline \multicolumn{7}{|l|}{ Between groups } \\
\hline Group & 93,11 & 1 & 93,11 & 0,421 & .519 & 0,007 \\
\hline Error & 13504,10 & 61 & 221,38 & & & \\
\hline \multicolumn{7}{|l|}{ Within group } \\
\hline Measurement & 5813,029 & 1 & 5813,029 & 66,473 & .000 & .521 \\
\hline Measurement * Group & 80,457 & 1 & 80,457 & 0,920 & .341 & .015 \\
\hline Error & 5334,400 & 61 & 87,449 & & & \\
\hline Total & 24825,096 & 62 & & & & \\
\hline
\end{tabular}

The scores of the groups were examined using independent samples t-test, no significant difference was found between the pretest $(\mathrm{t}(1,61)=-0,40, \mathrm{p}=.968)$ and posttest $(\mathrm{t}(1,61)=-1,02, \mathrm{p}=.312)$ scores. When Table 4 is examined, it is seen according to the 2 X 2 mixed ANOVA results that there was a significant increase in the posttest scores of both groups $(\mathrm{F}(1,61)=66,473, \mathrm{p}<.001)$. However, when Measurement * Group was examined, no significant difference was found $(\mathrm{F}(1,61)=0,920, \mathrm{p}=.341)$. In order to examine this finding in-depth, the data obtained via the qualitative data collection tools were used.

The participants in the experimental group tried to get experience point in order to obtain a badge, to take part in the face-to-face award activity and to be in an upper place in leaderboard. They stated that they completed the activities for this purpose. In addition, the participants in the experimental group did research to complete the activities and shared the information they obtained. It was seen that thanks to this, the participants got new knowledge or reinforced their current knowledge. In relation to this, one of the participants said "Probably, a competitive person, for example, I completed those activities because I wanted to take the first lead in the leaderboard, and I learned something in that way. I mean it had such an advantage. Perhaps, the purpose was to take the lead there, or to get a badge, or to win the wheel of fortune, but I learned something thanks to this. To me, gamification had quite good effects here. It slowly contributes to your learning. You asked me whether participation or learning? If there is no participation, then there will be no learning at all. (E, Focus group interview)". Based on the participant's view, it could be stated that different from the control group, learning occurred in the form of latent learning in the experimental group. However, since the influence of latent learning was not included in the scope of the study, the relationship between latent learning and academic achievement was not examined.

For the purpose of interpreting academic achievement, the data regarding the perceived difficulty levels of the activities were examined. The mean difficulty level was determined by calculating the mean scores regarding all the activities in the research process. According to the results of the independent samples $\mathrm{t}$-test, no significant difference was found between the groups with respect to the perceived mean difficulty level scores of the activities $(t(1,61)=-.738, p=.463)$. The relationship between the participants' academic achievement scores and the mean perceived difficulty level scores was examined using Pearson correlation coefficient (r). The results of this test revealed a low level of negatively significant relationship between academic achievement and perceived difficulty level $(r=-.274, p=.031)$. Accordingly, it could be stated that as the level of academic achievement increased, specialization in the related subject increased, which in turn led to a decrease in the perceived difficulty of the activities.

\section{DISCUSSIONS AND CONCLUSION}

The present study aimed to determine the effectiveness of the gamification elements in blended learning environments. In line with this purpose, the effectiveness of the gamification elements in blended learning environments was examined with respect to CoI, motivation and academic achievement. 
In the study, it was found that the teaching, social and cognitive presence mean scores obtained via the CoI data collection tool was not any significant difference between the groups in means of statically. This situation was thought to result from the fact that the participants in both groups reported similar views about the indicators of the CoI model. In addition, as required by the potential of blended learning (Garrison \& Kanuka, 2004; Torrisi-Steele \& Drew, 2013), the situation in question had positive influence on the two groups. In related literature, it is pointed out that blended learning is more effective when compared to traditional teaching and online teaching (Shea \& Bidjerano, 2012). In addition, Scott, Sorokti and Merrell (2016) hold the belief that gamification can be effective in blended learning environments, but this thought was not confirmed by the present research findings. Also, it could be stated that gamification elements in blended learning environments may have positive influence on the learner-learner interaction as awards help increase social interaction between students. Parallel to this finding, Hamari (2017) states that gamification is important for the establishment of social interactions. For this reason, as mentioned by Utomo et al. (2014), the students in the gamified environment participated more in the discussion activities. However, in the forums, it was seen that the irrelevant subjects mentioned by participants caused other participants to get bored, and this situation was thought to have negative influence on the participants' levels of social presence.

According to the data obtained via IMMS, no significant difference was found between the experimental and control groups' motivation scores. The reason for this finding is that, on the one hand, while gamification increases the motivation of the participants; on the other hand, as stated in the study by Hanus and Fox (2015), it can be said that the intrinsic motivation of the participants is reduced in long-term gamification experience. However, according to the participants' views, the gamification elements were found to be have positive effects on motivation in certain respects. In addition, the participants reported that the blended learning environment supported with gamification increased motivation as it was influential on experience point, going up in levels, competition, winning awards and being in higher positions in leaderboard. This finding is consistent with the findings of other studies in related literature which reported that gamification have positive influence on motivation (Barata, Gama, Jorge, \& Goncalves, 2015; Bell, 2014; Buckley \& Doyle, 2014; Dicheva et al., 2015; Kuo \& Chuang, 2016; Hamari, 2013; Hamari \& Koivisto, 2015; O’Donovan, Gain \& Marais, 2013; Sailer, et al., 2017; Tauer \& Harackiewicz, 2004). In addition, as mentioned by Zichermann and Cunningham (2011), going up in levels contributed to the participants' feeling of achievement. Thanks to this, it is thought that the dimension of satisfaction of the ARCS-V model was influenced positively. Also, it was found that the competitive environment created due to the experience point was positively influential on the participants' motivation, and this finding supports other studies in literature which point out that competition has positive influence on motivation (Bowser et al., 2013; Burguillo, 2010). Moreover, it was seen that the participants' motivations increased thanks to the awards. This finding is consistent with the one obtained by Keller (1987), who suggested using awards to increase the dimension of satisfaction of the ARCS-V model. In the present study, the participants stated that their motivations increased when they found a place in upper positions in the leaderboard and decreased in lower positions. However, this finding does not support the finding obtained by Lieberoth (2015), who reported that declaring one of the participants as the winner does not influence motivation. In line with all these findings, it could be stated that gamification contribute positively to motivation blended learning environments. For this reason, as stated by Landers, Bauer \& Callan (2017), the gamification elements such as leaderboard, point, etc. can be used as an effective tool for the gamify of assigned tasks.

In the study, the gamification elements had negative influence on motivation in some other respects. The participants in the experimental group stated that their motivations decreased to the restrictions, experience point and activity completion. As the present study was designed in accordance with blended learning, it was necessary to use face-to-face and online environments together. Therefore, the activities in online environment were restricted by time. It was found that depending on these restrictions, the participants' motivations were influenced negatively. This finding is consistent with the findings of other studies which reported that restrictions cause pressure on participants and thus lead to a decrease in their motivations (Lee \& Hammer, 2011; O’Donovan, 2012). As mentioned by Keller (2016), in such a case, it is though that the obstacles that prevent participants from being successful have negative influence on the dimension of confidence in the ARCS-V model. In addition, it was seen that experience point had negative influence on motivation with respect to the leaderboard, competitive environment and level. The participants' motivations 
increased when they took a place in upper positions in the leaderboard and decreased in the opposite case. This finding is parallel to Reeve and Deci's view (1996) that participants successful in competition have higher levels of motivation. On the other hand, it is important to remember the point made by Deci et al. (1981) that competition does not increase intrinsic motivation; in contrast, it even has negative influence on intrinsic motivation. In addition, Song, Kim, Tenzek, \& Lee (2013) point out that competition based on gamification is not influential on the motivations of individuals who do not have a competitive personal trait. Besides this, the findings of the study carried out by Hanus and Fox (2015) demonstrate that the motivation scores of the group in which gamification was not used did not differ significantly from those of the group which involved gamification. In addition, it was seen that the motivation increased when certain tasks were completed, and the badge was won in the gamified environment. This is consistent with the finding of the study by Huang and Hew (2018), indicating that the motivation of badges to be gained when participants complete certain tasks has increased. On the other hand, when tasks are not completed, and the badge is not won, there is also a decrease in motivation. In addition, in the study by Hamari, Hassan, \& Dias (2018), the gamification features can be perceived as more important by users who have easier goals, who are outcome-focused and who are more inclined to prove themselves to others. These results can be interpreted that users who do not have above traits can not percevied gamification as more important. Therefore, while use of gamification in blended learning environments increases participants' motivations in some respects, but it sometimes decreases their motivations in other respects.

In the study, it was found that the increase in the participants' posttest scores did not differ significantly depending on the groups. This finding is consistent with the one reported by McKernan et al., (2015) that awards in game-based education are not influential on learning. In addition, the finding in question contradicts with the finding obtained by Yildirim (2017), who reported that gamification-based teaching applications have positive influence on students' academic achievements. Considering that motivation has an impact on success in the game environment (Ozhan \& Kocadere, 2019); the findings of this research related to motivation show similar characteristics with the findings of academic achievement. Therefore, it can be said that the finding obtained in academic achievement may be the result of the motivation. Additionally, as stated by Zainuddin (2018), it can be said that thanks to the gamified environment, the participants emphasized that they learned new information. Besides academic achievement, the participants in the experimental group stated that they did the activities to obtain the gamification and that they thus developed and reinforced their current knowledge via latent learning. This finding supports the finding reported by Gibson et al., (2015) that participants obtain information thanks to their competition with others. Senemoglu (2011) points out that latent learning does not reflect upon one's performance. Within the scope of the present study, the participants' latent learning was not measured. Therefore, it is though that the participants' latent knowledge developed thanks to the gamification did not reflect upon the results of the achievement test.

In the study, it was found that the participants shared something just to get experience point and to maintain competition. Although the participants developed their knowledge via latent learning to get experience point, it should be remembered that the factor of competition was prior to developing one' knowledge getting information. Therefore, this finding could be said to contradict with the one obtained by Burguillo (2010), who reported that the competitive environment was influential on one's performance in learning. In addition, this situation regarding academic achievement is thought to be likely to result from the potential of blended learning. The reason is that in related literature, it is pointed out that blended learning contributes to meaningful learning (Garrison \& Kanuka, 2004; Garrison \& Vaughan, 2008). For this reason, the similar academic achievements of the groups in the present study could be said to be due to the influence of blended learning on meaningful learning. For this reason, the similar academic achievements of the groups in the present study are resulted from the influence of blended learning on meaningful learning. Also, the mentioned findings appear due to $\mathrm{CoI}$ and motivation-related findings as well as to the question of the effectiveness of gamification in a long-term investigation of gamification. For, Hanus and Fox (2015) explain that some game elements may feel more exciting at first, but over time the novelty can expires, and excitement can decrease. Similarly, Rachels, \& Rockinson-Szapkiw (2018) conducted a study that lasted 12 weeks and found that no differentiation between gamified and non-gamified groups in terms of language skills. Therefore, in future studies on gamification, it is recommended to examine the effect of time factor on academic achievement, motivation, and CoI. 


\section{LIMITATIONS AND DIRECTIONS FOR FUTURE RESEARCH}

In the study, the participants' latent learning was not measured. As participants are likely to do latent learning while getting the gamification elements, future studies could also measure this type of knowledge.

Although LMS, prepared for gamification using Moodle's plugins allows a number of gamification elements, the fact that gamification was limited to Moodle's plugins was another limitation of the present study. Considering the fact that gamification is context-specific, in future studies, gamification could be structured based on the research context.

The study was carried out with gamification elements giving instructions, progress bar, badge, level, experience point, leaderboard, award, restrictions of activities based on certain criteria such as level, time and activity completion and presenting notifications to participants regarding the activities. Considering having more different gamification components in the related literature (Karatas, 2014), future studies could conduct with different kind of elements. Furthermore, in some cases, the use of gamification elements may create a negative situation in terms of academic achievement. For example, in the study by Christy \& Fox (2014), it was seen that the leaderboard adversely affected academic achievement. In addition, it is stated in the literature review studies (Majuri, Koivisto, \& Hamari, 2018; So \& Seo, 2018) that the gamification and gamification elements can have some negative effects despite the other positive results. Therefore, it is recommended that the gamification elements should be selected as consistent with context in the future studies.

Another limitation in this research is that despite the IMMS having four factors in its original version, two factors version are adapted to Turkish by Kutu and Sozbilir (2010) and used in this study. However, to conduct gamification and motivation researchers with IMMS, its four factors version is recommended while doing similar studies. Different data collection tools for motivation other than IMMS can be used for investigating effect of gamification.

\section{CONCLUSIONS}

This study aimed to investigate the effectiveness of gamification elements in blended learning environments within the context of CoI framework, academic achievement and motivation. Despite some limitations about using gamification elements in blended learning in the study, these elements contribute positive effects to students' latent learning. According to quantitative results, no significant difference was found between the experiment and control groups' teaching presence, social presence, cognitive presence, academic achievement and motivation scores. When qualitative results show the fact that gamification elements in blended learning environments have positive effect on these variables, on the other hand vice versa. In conclusion, the gamification elements in blended learning environments was to have both positive and negative effects with respect to the CoI model, academic achievement and motivation.

Acknowledgements: This study is a part of the first author's Ph.D. dissertation, which is supervised by the second author. This work was supported by the Anadolu University Scientific Research Projects Commission [1507E555]; Anadolu University, Eskisehir, Turkey. 


\section{BIODATA and CONTACT ADDRESSES of AUTHORS}

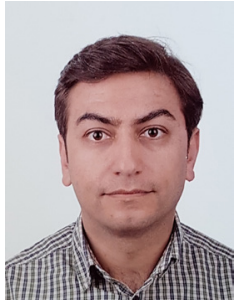

Dr. Can MESE, is an Assistant Professor of Education Faculty, Yozgat Bozok University. Dr. Mese gained his Ph.D. in Computer Education and Instructional Technology at August, 2016. His academic interest areas are gamification, game based learning, blended learning, multimedia, interest and emotion. He has submitted over than 15 papers to international meetings. He has also published his academic works in national and international journals.

Can MESE

Address: Faculty of Education, Department of Elementary Education

Yozgat Bozok University, Erdogan Akdag Campus, 66900, Yozgat, TURKEY

Phone: +90 5066575849

E-mail: canmese@gmail.com

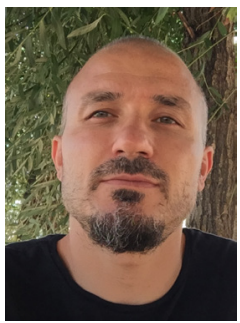

Dr. Ozcan Ozgur DURSUN, is an Assistant Professor of Education Faculty, Anadolu University. Dr. Dursun gained his Ph.D. in Communication Design at June, 2011. His academic interest areas are multimedia design, learning communities, social network usage, e-learning and cyber behaviors. He has over than 5 journal articles published in international indexes, over than 15 book chapters and other national and international articles, over than 40 papers submitted to international meetings.

Ozcan Ozgur DURSUN

Address: Faculty of Education, Computer Education and Instructional Technologies Department Anadolu University, Yunus Emre Campus, 26470, Tepebasi, Eskisehir, TURKEY

Phone: +90 5327980144

E-mail: oodursun@anadolu.edu.tr

\section{REFERENCES}

Akbulut, Y. (2010). Sosyal bilimlerde SPSS uygulamalari (SPSS Applications in Social Sciences). Istanbul: Ideal Kultur Yayincilik.

Al-Qahtani, A. A., \& Higgins, S. E. (2013). Effects of traditional, blended and e-learning on students' achievement in higher education. Journal of Computer Assisted Learning, 29(3), 220-234.

Aldemir, T., Celik, B., \& Kaplan, G. (2018). A qualitative investigation of student perceptions of game elements in a gamified course. Computers in Human Behavior, 78, 235-254.

Arbaugh, J. B., Cleveland-Innes, M., Diaz, S. R., Garrison, D. R., Ice, P., Richardson, J. C., \& Swan, K. P. (2008). Developing a community of inquiry instrument: Testing a measure of the community of inquiry framework using a multi-institutional sample. The Internet and Higher Education, 11(3), 133-136.

Barata, G., Gama, S., Jorge, J., \& Goncalves, D. (2015). Gamification for smarter learning: tales from the trenches. Smart Learning Environments, 2(1), 1-23.

Bell, K. R. (2014). Online 3.0 the rise of the gamer educator the potential role of gamification in online (Doctoral dissertation). Available from ProQuest Dissertations and Theses database. (UMI No. 1615085697).

Bowser, A., Hansen, D., He, Y., Boston, C., Reid, M., Gunnell, L., \& Preece, J. (2013). Using gamification to inspire new citizen science volunteers. Proceedings of the first international conference on gameful design, research, and applications. New York: ACM, s.18-25. 
Buckley, P., \& Doyle, E. (2016). Gamification and student motivation. Interactive Learning Environments, 24(6), 1162-1175.

Burguillo, J. C. (2010). Using game theory and competition-based learning to stimulate student motivation and performance. Computers and Education, 55(2), 566-575.

Buyukozturk, S., Kilic Cakmak, E. K., Akgun, O. E., Karadeniz, S., \& Demirel, F. (2014). Bilimsel arastirma yontemleri (Scientific Research Methodology). Ankara: Pegem Akademi Yayincilik.

Caputo, M. G. (2010). Undergraduate mathematics students' attitudes towards online mathematics education and achievement in a hybrid calculus (Doctoral dissertation). Available from ProQuest Dissertations and Theses database. (UMI No. 756255034).

Chang, C. C., Shu, K. M., Liang, C., Tseng, J. S., \& Hsu, Y. S. (2014). Is blended e-learning as measured by an achievement test and self-assessment better than traditional classroom learning for vocational high school students? The International Review of Research in Open and Distributed Learning, 15(2), 213-231.

Cheng, G., \& Chau, J. (2016). Exploring the relationships between learning styles, online participation, learning achievement and course satisfaction: An empirical study of a blended learning course. British Journal of Educational Technology, 47(2), 257-278.

Creswell, J. W. (2014). Research design: Qualitative, quantitative, and mixed methods approaches. (4th edition). Los Angles, London, New Delhi, Singapore, Washington: Sage.

Christy, K. R., \& Fox, J. (2014). Leaderboards in a virtual classroom: A test of stereotype threat and social comparison explanations for women's math performance. Computers \& Education, 78, 66-77.

Davis, K., \& Singh, S. (2015). Digital badges in afterschool learning: documenting the perspectives and experiences of students and educators. Computers and Education, 88, 72-83.

Deci, E. L., Betley, G., Kahle, J., Abrams, L., \& Porac, J. (1981). When trying to win competition and intrinsic motivation. Personality and social psychology bulletin, 7(1), 79-83.

Deterding, S., Dixon, D., Khaled, R., \& Nacke, L. (2011). From game design elements to gamefulness: defining gamification. 15th International Academic MindTrek Conference: Envisioning Future Media Environments, Tampere: ACM, s. 9-15.

Dichev, C., \& Dicheva, D. (2017). Gamifying education: what is known, what is believed and what remains uncertain: a critical review. International Journal of Educational Technology in Higher Education, 14(9). 2-36.

Dicheva, D., Dichev, C., Agre, G., \& Angelova, G. (2015). Gamification in education: a systematic mapping study. Educational Technology, \& Society, 18(3), 75-88.

Domínguez, A., Saenz-de-Navarrete, J., De-Marcos, L., Fernandez-Sanz, L., Pagés, C., \& Martínez-Herraiz, J. J. (2013). Gamifying learning experiences: Practical implications and outcomes. Computers and Education, 63, 380-392.

Draffan, E. A. \& Rainger, P. (2006). A model for the identification of challenges to blended learning, ALT-J, 14(1), 55-67

Drysdale, J. S., Graham, C. R., Spring, K. J., \& Halverson, L. R. (2013). An analysis of research trends in dissertations and theses studying blended learning. The Internet and Higher Education, 17, 90-100.

Fraenkel, J. R., Wallen, N. E., \& Hyun, H. (2011). How to design and evaluate research in education. (8th ed.). New York: McGrawHill.

Garrison, D. R., \& Arbaugh, J. B. (2007). Researching the community of inquiry framework: Review, issues, and future directions. The Internet and Higher Education, 10(3), 157-172.

Garrison, D. R., \& Kanuka, H. (2004). Blended learning: Uncovering its transformative potential in higher education. The Internet and Higher Education, 7(2), 95-105. 
Garrison, D. R., \& Vaughan, N. D. (2008). Blended learning in higher education: Framework, principles, and guidelines. San Francisco, CA: John Wiley, \& Sons.

Garrison, D. R., Anderson, T., \& Archer, W. (1999). Critical inquiry in a text-based environment: Computer conferencing in higher education. The Internet and Higher Education, 2, 87-105.

Garrison, D. R., Anderson, T., \& Archer, W. (2010). The first decade of the community of inquiry framework: A retrospective. The Internet and Higher Education, 13(1), 5-9.

Gibson, D., Ostashewski, N., Flintoff, K., Grant, S., \& Knight, E. (2015). Digital badges in education. Education and Information Technologies, 20(2), 403-410.

Golding, C. (2015). The Community of inquiry: blending philosophical and empirical research. Studies in Philosophy and Education, 34(2), 205-216.

Graham, C. R., Henrie, C. R., \& Gibbons, A. S. (2014). Developing models and theory for blended learning research. Blended learning: Research perspectives, 2, 13-33.

Halverson, L. R., Graham, C. R., Spring, K. J., Drysdale, J. S., \& Henrie, C. R. (2014). A thematic analysis of the most highly cited scholarship in the first decade of blended learning research. The Internet and Higher Education, 20, 20-34.

Hamari, J. (2013). Transforming homo economicus into homo ludens: A field experiment on gamification in a utilitarian peer-to-peer trading service. Electronic commerce research and applications, 12(4), 236-245.

Hamari, J. (2017). Do badges increase user activity? A field experiment on the effects of gamification. Computers in Human Behavior, 71. 469-478.

Hamari, J., \& Koivisto, J. (2014). Measuring flow in gamification: Dispositional flow scale-2. Computers in Human Behavior, 40, 133-143.

Hamari, J., Hassan, L., \& Dias, A. (2018). Gamification, quantified-self or social networking? Matching users' goals with motivational technology. User Modeling and User-Adapted Interaction, 28(1), 35-74.

Hamza, M. F. (2015). Effectiveness of using blended learning versus traditional teaching on the nursing students' performance (Masters thesis, Cairo: Ain Shams University). Retrieved from http://www. philadelphia.edu.jo/newlibrary/eng/english-books/671-english-books/102213-engb-102213

Hanus, M. D., \& Fox, J. (2015). Assessing the effects of gamification in the classroom: A longitudinal study on intrinsic motivation, social comparison, satisfaction, effort, and academic performance. Computers and Education, 80, 152-161.

Harman, K., Koohang, A., \& Paliszkiewicz, J. (2014). Scholarly interest in gamification: a citation network analysis. Industrial Management \& Data Systems, 114(9), 1438-1452.

Hebebci, M. T., \& Ertugrul, U. (2015). Turkiye'de harmanlanmis ogrenme egilimleri: bir literatur calismasi. Adiyaman University Journal of Social Sciences, 19, 195-219.

Hoic-Bozic, N., Dlab, M. H., \& Mornar, V. (2016). Recommender system and web 2.0 tools to enhance a blended learning model. IEEE Transactions on Education, 59(1), 39-44.

Hu, L., \& Bentler, P. M. (1999). Cutoff criteria for fit indexes in covariance structure analysis: Conventional criteria versus new alternatives. Structural Equation Modeling: A Multidisciplinary Journal, 6(1), $1-55$.

Huang, B., \& Hew, K. F. (2018). Implementing a theory-driven gamification model in higher education flipped courses: Effects on out-of-class activity completion and quality of artifacts. Computers \& Education, 125, 254-272.

So, H. J., \& Seo, M. (2018). A systematic literature review of gamebased learning and gamification research in Asia from: Routledge International Handbook of Schools and Schooling in Asia Routledge. Accessed on: 26 Jan 2019 
Islam, A. N., \& Azad, N. (2015). Satisfaction and continuance with a learning management system: Comparing perceptions of educators and students. The International Journal of Information and Learning Technology, 32(2), 109- 123.

Kanchanamala, P., \& Muppidi, S. (2016). SIPAI: An integrated learning model of self learning, inquiry based, problem solving, activity based, and instructional learning for engineering education. In Advanced Computing (IACC), 2016 IEEE 6th International Conference on (pp. 820-824). IEEE.

Kapp, K. M. (2012). The gamification of learning and instruction: game-based methods and strategies for training and education. San Francisco, CA: John Wiley, \& Sons.

Karatas, E. (2014). Egitimde oyunlastirma: arastirma egilimleri. Journal of Kirsehir Education Faculty (KEFAD), 15(2), 315-333.

Keller, J. M. (1987). Development and use of the ARCS model of instructional design. Journal of Instructional Development, 10(3), 2-10.

Keller, J. M. (2010). Motivational design for learning and performance: The ARCS model approach. New York, Dordrecht, Heidelberg, London: Springer Science \& Business Media.

Keller, J. M. (2008). An integrative theory of motivation, volition, and performance. Technology, Instruction, Cognition, and Learning, 6(2), 79-104.

Keller, J. M. (2016). Motivation, learning, and technology: applying the ARCS-V motivation model.

Kidd, T. T. (2010). A brief history of eLearning. T. T. Kidd (Ed.), Online Education and Adult Learning: New Frontiers for Teaching Practices icinde (s. 46-53). Hershey, New York: IGI Global. Participatory Educational Research (PER), 3(2), 1-13.

Koivisto, J., \& Hamari, J. (2019). The rise of motivational information systems: A review of gamification research. International Journal of Information Management, 45, 191-210.

Kuo, M. S., \& Chuang, T. Y. (2016). How gamification motivates visits and engagement for online academic dissemination-An empirical study. Computers in Human Behavior, 55, 16-27.

Kutu, H., \& Sozbilir, M. (2011). Ogretim materyalleri motivasyon anketinin Turkce'ye uyarlanmasi: guvenirlik, \& gecerlik calismasi. Necatibey Faculty of Education, Electronic Journal of Science and Mathematics Education, 5(1), 292-312.

Landers, R. N., Bauer, K. N., \& Callan, R. C. (2017). Gamification of task performance with leaderboards: A goal setting experiment. Computers in Human Behavior, 71, 508-515.

Lee, J. J., \& Hammer, J. (2011). Gamification in education: What, how, why bother? Academic Exchange Quarterly, 15(2), 146-147.

Lieberoth, A. (2015). Shallow gamification testing psychological effects of framing an activity as a game. Games and Culture, 10(3), 229-248.

Lonn, S., Teasley, S. D., \& Krumm, A. E. (2011). Who needs to do what where?: Using learning management systems on residential vs. commuter campuses. Computers and Education, 56(3), 642-649.

MacCallum, R. C., Browne, M. W., \& Sugawara, H. M. (1996). Power analysis and determination of sample size for covariance structure modeling. Psychological methods, 1(2), 130.

Macfadyen, L. P., \& Dawson, S. (2012). Numbers are not enough. why e-learning analytics failed to inform an institutional strategic plan. Educational Technology, \& Society, 15 (3), 149-163.

Majuri, J., Koivisto, J., \& Hamari, J. (2018). Gamification of education and learning: A review of empirical literature. In 2nd International GamiFIN Conference, Pori, Finland (pp. 21-23).

Marczewski, A. (2015). Even ninja monkeys like to play: gamification, game thinking, \& motivational design. Gamified UK. 
McKernan, B., Martey, R. M., Jennifer Stromer-Galley, Kenski. K., Clegg, B. A., Folkestad, J. E., ... Strzalkowski, T. (2015). McKWe don't need no stinkin'badges: The impact of reward features and feeling rewarded in educational games. Computers in Human Behavior, 45, 299-306.

Means, B., Toyama, Y., Murphy, R., \& Baki, M. (2013). The effectiveness of online and blended learning: A meta-analysis of the empirical literature. Teachers College Record, 115(3), 1-47.

Mekler, E. D., Bruhlmann, F., Tuch, A. N., \& Opwis, K. (2017). Towards understanding the effects of individual gamification elements on intrinsic motivation and performance. Computers in Human Behavior, 71. 525-534.

Mert, Y., \& Samur, Y. (2018). Students' Opinions Toward Game Elements Used in Gamification Application. Turkish Online Journal of Qualitative Inquiry, 9(2), 70-101.

Miller, M. D., Linn, R. L., \& Gronlund, E. N. (2009). Measurement and assessment in teaching. NJ: Pearson Education Group.

Moore, M. (1989). Three types of interaction. The American Journal of Distance Education, 3 (2), 1-6.

Moskal, P., Dziuban, C., \& Hartman, J. (2013). Blended learning: A dangerous idea? The Internet and Higher Education, 18, 15-23.

Nsibande, G. N. (2014). Face-to-face, print-based or e-learning? a case study of ict integration in alternative instructional modalities at the university of swaziland (Doctoral dissertation, Johannesburg, South Africa: The University of Witwatersrand). Retrieved from http://www.philadelphia.edu.jo/ newlibrary/eng/english-books/671-english-books/102213-engb-102213

O'Donovan, S. (2012). Gamification of the games course. Acesso em, 17, 1-8.

O'Donovan, S., Gain, J., \& Marais, P. (2013). A case study in the gamification of a university-level games development course. The South African Institute for Computer Scientists and Information Technologists Conference, East London: ACM, s. 242-251.

Ozdamar, K. (2004). Paket programlarla istatistiksel veri analizi( Statistical Data Analysis in SPSS). Eskisehir: Kaan Kitabevi.

Ozgur, H., Cuhadar, C., \& Akgun, F. (2018). Egitimde Oyunlastirma Arastirmalarinda Guncel Egilimler. Kastamonu Universitesi Kastamonu Egitim Dergisi, 99 (99), 1-9.

Ozhan, S. C., \& Kocadere, S. A. (2019). The Effects of Flow, Emotional Engagement, and Motivation on Success in a Gamified Online Learning Environment. Journal of Educational Computing Research. Online first. 1-26. doi: 10.1177/0735633118823159.

Ozturk, E. (2012). Arastirma toplulugu olceginin Turkceye uyarlanmasi: gecerlik ve guvenirlik calismasi (An Adaptation of the Community of Inquiry Index: The Study of Validity and Reliability). Ilkogretim Online, 11(2). 408-422.

Patchan, M. M., Schunn, C. D., Sieg, W., \& McLaughlin, D. (2016). The effect of blended instruction on accelerated learning. Technology, Pedagogy and Education, 25(3), 269-286.

Rachels, J. R. \& Rockinson-Szapkiw, A. J. (2018). The effects of a mobile gamification app on elementary students' Spanish achievement and self-efficacy, Computer Assisted Language Learning, 31 (1-2), 72-89. doi: $10.1080 / 09588221.2017 .1382536$

Reeve, J., \& Deci, E. L. (1996). Elements of the competitive situation that affect intrinsic motivation. Personality and Social Psychology Bulletin, 22, 24-33.

Sailer, M., Hense, J. U., Mayr, S. K., \& Mandl, H. (2017). How gamification motivates: An experimental study of the effects of specific game design elements on psychological need satisfaction. Computers in Human Behavior, 69, 371-380

Scott, K. S., Sorokti, K. H., \& Merrell, J. D. (2016). Learning "beyond the classroom" within an enterprise social network system. The Internet and Higher Education, 29, 75-90. 
Seixas, L. d., Gomes, A. S., \& de Melo Filho, I. J. (2016). Effectiveness of gamification in the engagement of students. Computers in Human Behavior, 58, 48-63.

Senemoglu, N. (2011). Gelisim ogrenme, \& ogretim: Kuramdan uygulamaya (19th edition). Ankara: Pegem Akademi Yayincilik.

Sharma, S., Mukherjee, S., Kumar, A., \& Dillon, W. (2005). A simulation study to investigate the use of cutoff values for assessing model fit in covariance structure models. Journal of Business Research, 58(1), 935-43.

Shea, P. ve Bidjerano, T. (2012). Learning presence as a moderator in the community of inquiry model. Computers and Education, 59(2), 316-326.

Smith, J. G., \& Suzuki, S. (2015). Embedded blended learning within an Algebra classroom: a multimedia capture experiment. Journal of Computer Assisted Learning, 31(2), 133-147.

So, H. J., \& Brush, T. A. (2008). Student perceptions of collaborative learning, social presence and satisfaction in a blended learning environment: relationships and criticalfactors. Computers and Education, 51(1), 318-336.

Song, H., Kim, J., Tenzek, K. E., \& Lee, K. M. (2013). The effects of competition and competitiveness upon intrinsic motivation in exergames. Computers in Human Behavior, 29(4), 1702-1708.

Staker, H., \& Horn, M. B. (2012). Classifying K-12 blended learning. Retrieved October 12, 2018 http:// files.eric.ed.gov/fulltext/ED535180.pdf.

Su, C. H., \& Cheng, C. H. (2015). A mobile gamification learning system for improving the learning motivation and achievements. Journal of Computer Assisted Learning, 31, 268-286.

Subhash, S., \& Cudney, E. A. (2018). Gamified learning in higher education: A systematic review of the literature. Computers in Human Behavior, 87, 192-206.

Sumer, N. (2000). Yapisal esitlik modelleri: Temel kavramlar, \& ornek uygulamalar. Turkish Journal of Psychology, 3(6), 49-74.

Tabachnick, B. G., \& Fidell, L. S. (2007). Using multivariate statistics (5th Edition). Boston, MA: Pearson.

Tamim, R. M., Bernard, R. M., Borokhovski, E., Abrami, P. C., \& Schmid, R. F. (2011). What forty years of research says about the impact of technology on learning a second-order meta-analysis and validation study. Review of Educational research, 81(1), 4-28.

Tauer, J. M., \& Harackiewicz, J. M. (2004). The effects of cooperation and competition on intrinsic motivation and performance. Journal of personality and social psychology, 86(6), 849-861.

Torrisi-Steele, G., \& Drew, S. (2013). The literature landscapeof blended learning in higher education: the need for better understanding of academic blended practice. International Journal for Academic Development, 18(4), 371-383.

Tuysuz, C., \& Balaman, F. (2011). Harmanlanmis ogrenme modelinin 7. sinif ogrencilerinin fen, \& teknoloji dersindeki basarilarina, tutumlarina, \& motivasyonlarina etkisinin incelenmesi(Researching the effect of blended learning model on the science and technology course success, attitudes and motivations of $7^{\text {th }}$ class students). Bati Anadolu Egitim Bilimleri Dergisi (BAED), 2(4), 75-90.

Utomo, A. Y., Amriani, A., Aji, A. F., Wahidah, F. R., \& Junus, K. M. (2014). Gamified e-learning model based on community of inquiry. In Advanced Computer Science and Information Systems (ICACSIS), 2014 International Conference on (pp. 474-480). IEEE.

Vaughan, N. D., Cleveland-Innes, M., \& Garrison, D. R. (2013). Teaching in blended learning environments: Creating and sustaining communities of inquiry. Edmonton: Athabasca University Press.

Vaughan, N., \& Garrison, D. R. (2005). Creating cognitive presence in a blended faculty development community. The Internet and higher education, 8(1), 1-12. 
Vaughn, S., Schumm, J. S., \& Sinagub, J. M. (1996). Focus group interviews in education and psychology. London: Sage.

Werbach, K., \& Hunter, D. (2012). For the win: how game thinking can revolutionize your business. Philadelphia, PA: Wharton Digital Press.

Yildirim, I. (2017). The effects of gamification-based teaching practices on student achievement and students' attitudes toward lessons. The Internet and Higher Education, 33, 86-92.

Yilmaz, M., \& O'Connor, R. (2016). A Scrumban integrated gamification approach to guide software process improvement: a Turkish case study. Tehnicki Vjesnik (Technical Gazette), 23(1), 237-245.

Xu, D., \& Jaggars, S. S. (2014). Performance gaps between online and face-to-face courses: Differences across types of students and academic subject areas. The Journal of Higher Education, 85(5), 633659.

Zainuddin, Z. (2018). Students' learning performance and perceived motivation in gamified flipped-class instruction. Computers \& Education, 126, 75-88. 